\title{
Prospective chemistry teachers' cognitive structures about the concept of globalization
}

\author{
Şenol Şen ${ }^{1 *}$, Sinem Dinçol Özgür ${ }^{1}$, and Senar Temel ${ }^{1}$ \\ ${ }^{1}$ Hacettepe University, Beytepe, Ankara, 06800, Turkey
}

\begin{abstract}
This study aims to determine prospective chemistry teachers' cognitive structures about the concept of globalization. The study employs case study- one of qualitative research methods. 20 prospective chemistry teachers were included in the research. The participants were chosen in purposeful sampling method. The research data were collected through a test of three open-ended questions developed by the researchers. The prospective teachers were asked questions on what globalization meant, what the environmental consequences of globalization were, and what the effects of globalization on the world were and they were required to answer the questions in writing. The written answers that prospective chemistry teachers gave to the open-ended questions will be put to content analysis. The findings to be obtained through content analysis were divided into themes related to the concept of globalization and categories defined. After the analysis of the themes and categories, prospective chemistry teachers' cognitive structures about the concept of globalization were revealed and then the findings were discussed in details.
\end{abstract}

Keywords: Case study, cognitive structure, content analysis, globalisation

\section{Introduction}

Cognitive structures are the schemata through which students organise various concepts and they relate them so that they can understand a subject better $[1,2]$. Deficiencies or lacking conceptual links in those schemata result in difficulties in learning new knowledge or adding new concepts into the inconsistent structure of knowledge [3]. Analysing students' cognitive structures informs educators of their knowledge structures, prior knowledge and probable misconceptions, and this also makes it possible to notice their knowledge gaps [4, 5]. This study aims to determine prospective chemistry teachers' cognitive structures about the concept of globalization by setting out from the significance of investigating cognitive structure. Globalization causes nations to face environmental problems that they cannot solve on their own. Those negative effects and harms of globalization especially in terms of environment can only be prevented or reduced through solutions and precautions involving global cooperation, international agreement, solidarity and universal approaches [6]. Thus, this study intends to analyse the cognitive structures of prospective teachers-who will probably have a voice in the future about the environment- about the concept of

\footnotetext{
* Corresponding author: schenolschen@gmail.com
} 
globalization. A review of literature makes it clear that only a small number of studies analysing students' cognitive structures about various environmental issues [greenhouse effect and global warming- 7, 8; carbon cycle- 9] are available. On reviewing literature of globalization, on the other hand, it was found that studies investigating the process of globalization, the reflections of globalization into education, the globalization of education $[10,11,12,13]$ in general and studies analysing prospective social studies teachers' views on globalization [14], the youth's perceptions of identity in Turkey in the process of globalization [15] and discussions on globalization in Turkey [16] were available. In addition to that, there were also studies on the way globalization influenced education [17] and educational policies [18] throughout the world as well as studies about what globalization meant for changes in education [19]. Yet, the absence of studies analysing the concept of globalization along with students'/prospective teachers' cognitive structures demonstrates the importance of this current study in that it is the first in relevant literature.

\subsection{The aim of the study}

This study aimed to determine prospective chemistry teachers' cognitive structures about the concept of globalization.

\section{Method}

Case study, one of qualitative research methods, was employed in this study. Case study was preferred due to the fact that it was a research method which was based on the questions of how and why and which enabled researchers to investigate in depth a phenomenon or event which they could not control [20].

\subsection{Study group}

The study group was composed of prospective chemistry teachers. All of the participants took a course in Environmental Protection in 2017-2018 academic year. The participants were chosen through purposeful sampling. Purposeful sampling is a method enabling researchers to examine the situations having rich information in depth and thus to illuminate better the questions that a study focuses on [21]. All the participants- who were aged between 21 and 23- were included in the study on the basis of volunteering. Prior to the study, they were informed of the content, evaluation of the data and confidentiality of their names.

\subsection{Data collection tool}

The research data were collected through a test of three open-ended questions developed by the researchers. The test questions were prepared by reviewing the studies available in the literature. The data were collected in the spring semester of 2017-2018 academic year. The participants were allowed 20 minutes to respond to the questions. They were asked questions about what globalization meant, what the effects of globalization on the world were and what the environmental consequences of globalization were; and they were required to answer the questions in writing. 


\subsection{Analyses of the data}

The written answers given by the prospective teachers to the open-ended questions will be put to content analysis. Content analysis was preferred so as to reach the concepts and relations which would be able to explain the data collected [20]. The findings obtained through content analysis analysed in themes and then categories will be distinguished. Following the analyses, codes were created with themes and categories related to the concept of globalization. Expert opinion was consulted in analysing the qualitative data and thus efforts were made to raise internal validity. "Similarities and differences in coding" between the two encoders were compared and interrater reliability was found to be $91 \%$. Reliability formula suggested by Miles and Huberman [22] was used in calculating the reliability in this study. $70 \%$ reliability should be attained at the minimum in qualitative studies $[22,20]$. Efforts were made in this way to increase reliability in this study.

\section{Findings}

The findings obtained through content analysis are shown in Table 1. Whereas nothing was written in the frequency (f) part of the Table for the data which were mentioned only once, the number of statements repeated more than once were shown with a number.

Having analyzed the themes and categories distinguished, efforts were made to reveal prospective chemistry teachers' cognitive structures about the concept of globalization. As is clear from Table 1, prospective chemistry teachers' cognitive structures were considered in three categories- namely, "the definition of the concept of globalization", "environmental consequences of the concept of globalization" and "the effects of globalization on the world (environmental, economic, technological, cultural and political dimensions)"

As evident from the prospective teachers' statements in the category of "the definition of the concept of globalization", two of the prospective teachers mentioned the process of integrating societies and cultures, world's becoming an open market and the process of international integration; six mentioned regional phenomena's becoming global phenomena and five mentioned nation's coming together and searching for solutions to environmental problems.

Prospective teachers' statements in the category of "the environmental consequences of the concept of globalization", on the other hand, demonstrated that three of them mentioned increase in greenhouse gases in consequence of economic development; four mentioned emergence of environmental problems in consequence of increase in competition between countries and companies; three mentioned world countries' search for solutions to environmental problems; four mentioned countries' remaining in contact for the environment; three mentioned environmental problems being the concern for all humans and fourteen mentioned increase in environmental problems. 


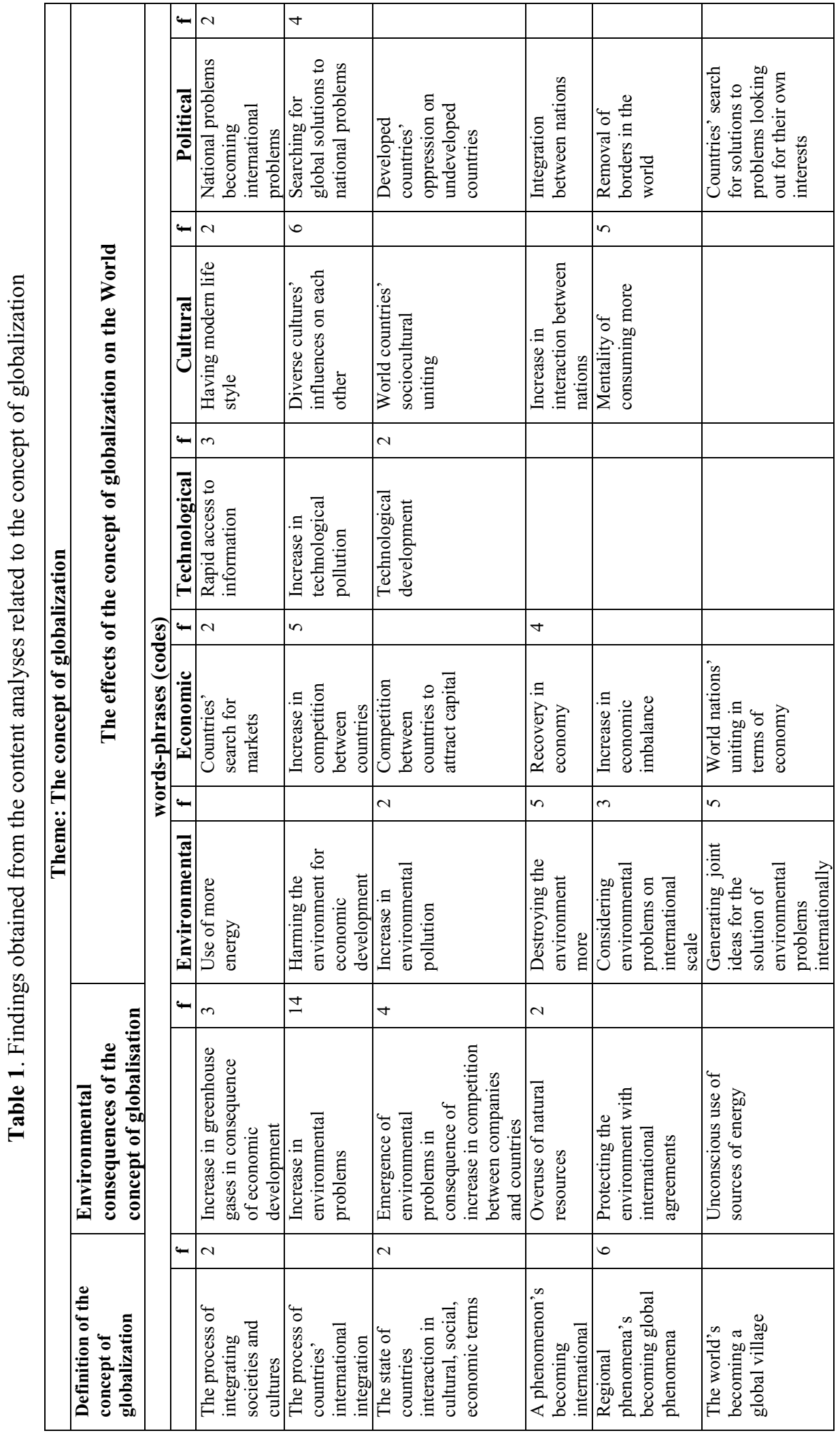




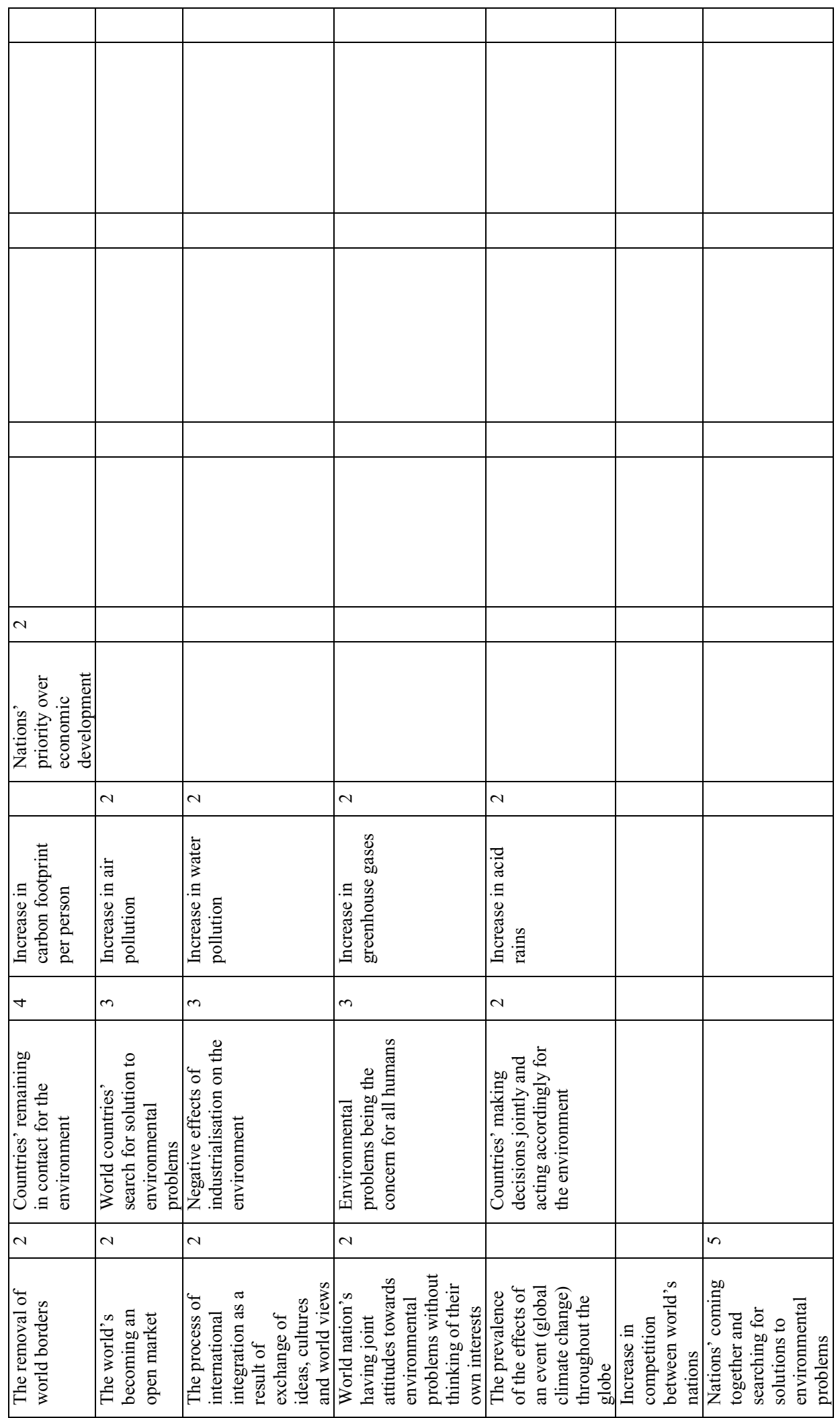


An examination of the prospective teachers' statements in the category of "the effects of the concept of globalization on the world (environmental, economic, technological, cultural and political dimensions)" showed that five of the prospective teachers mentioned destroying the environment more; two mentioned increase in environmental pollution; one mentioned increase in carbon footprint per person; three mentioned considering environmental problems on international scale and five mentioned generating joint ideas for the solution of environmental problems internationally. On economic dimension, two of them mentioned countries' search for markets, five mentioned increase in competition between countries and two mentioned countries' priority over economic development. On technological dimension three mentioned rapid access to information, one mentioned increase in technological pollution and two mentioned development in technology. On cultural dimension two mentioned having modern life style, six mentioned diverse cultures influences over each other and five mentioned mentality of consuming more. On political dimension two participants mentioned national problems becoming international problems, four mentioned searching for global solutions to national problems and one mentioned countries' search for solutions to problems looking out for their own interests.

\section{Conclusion And Discussion}

The written answers prospective teachers had given to the open-ended questions about the concept of globalization were put to content analysis. Following the analysis, prospective teachers' knowledge of the concept of globalization was analyzed in three categories.

On examining the participants' statements in the category of "the definition of the concept of globalization" it was found that they generally described globalization as the process of integrating societies and cultures; the state of countries' interaction in cultural, social and economic terms; the removal of world's borders and as world's becoming an open market. However, the percentage of the participants making these statements $(10 \%)$ was low. The percentage of those describing globalization in connection with environmental problems and environmental phenomena was higher. Accordingly, 30\% described globalization as regional environmental phenomena's becoming global phenomena and $25 \%$ described it as countries' coming together and searching for solutions. These findings demonstrated that prospective teachers had deficiencies in knowledge about the definition of the concept.

An examination of the prospective teachers' statements in the category of "environmental consequences of the concept of globalization" demonstrated that the majority $(70 \%)$ mentioned increase in environmental problems, $15 \%$ mentioned increase in greenhouse gases in consequence of economic development and 15\% mentioned negative effects of industrialization on the environment. Although the fact that the participants mentioned world countries' search for solutions to environmental problems $(25 \%)$, environmental problems being concern for all humans $(15 \%)$, countries' remaining in contact for the environment (20\%) and countries acting together by making joint decisions $(10 \%)$ demonstrated that approaches such as cooperation between countries and solidarity should be adopted for the solution of environmental problems; low percentages indicated lacks in their knowledge.

The participants' statements in the category of "the effects of the concept of globalization on the world" were analyzed on five dimensions. Accordingly, the participants were found to have mentioned increase in environmental pollution, increase in air pollution, increase in water pollution, increase in greenhouse gases and increase in acid rains; but the rate of those making the statements was very low (10\%). The participants also associated environmental effects with the concept of globalization and mentioned such 
issues as considering environmental problems on international scale (15\%) and generating joint ideas internationally $(25 \%)$. As to the economic effects of globalization, the prospective teachers mentioned countries' search for markets $(10 \%)$, increase in capital in countries $(5 \%)$, increase in competition between countries $(25 \%)$ and increase in economic imbalance $(5 \%)$ as negative effects while $20 \%$ of them mentioned economic recovery as the positive effect. As the technological effects of globalization, they mentioned rapid access to information (15\%), technological development $(10 \%)$ and increase in technological pollution $(5 \%)$. As the cultural effects, they made limited number of statements about such issues as having modern life style (10\%), diverse cultures' influences on one another $(30 \%)$ and mentality of consuming more $(25 \%)$. They mentioned national problems' becoming international problems (10\%), searching for solutions to national problems globally $(20 \%)$, developed countries' oppressing undeveloped countries $(5 \%)$ and removal of the borders in the world $(5 \%)$ in terms of the political effects of globalization.

On evaluating the results in general, it was seen that the percentage of prospective teachers defining the concept of globalization within the framework of environment was higher although they made general definitions of the concept. In other words, they defined the concept of globalization by associating it with the environment. It was found that the percentage of those stating that globalization caused increase in environmental problems was quite high. The percentage of participants saying that world countries should search for solutions to the problems together and that they should generate solutions together was low. On examining the prospective teachers' statements in the category of the effects of globalization on the world it was found that they had mentioned 5 dimensions of globalization. On comparing the dimensions, it was found that the participants suggested limited number of ideas on economic, technological, cultural and political dimensions but that they put forward more ideas on environmental dimension. In parallel to those statements, this study also reached general ideas that countries would be in interaction in consequence of globalization, that global solutions would be searched to national problems and that diverse cultures would influence each other. Although these results were consistent with the ones obtained by Kaya [16], Fidan [15] and Gürbüz [14]; it may be said that prospective teachers' cognitive structures about the concept of globalization are not rich enough and that therefore they are lacking in knowledge.

\section{References}

1. Novak, J. \& Cañas, A.J. The theory underlying concept maps and how to construct them. Technical Report IHMC CmapTools 2006-1. Florida Institute for Human and Machine Cognition, Pensacola, (2006).

2. Novak J. D. Learning, creating, and using knowledge: concept maps as facilitative tools in schools and corporations. Journal of e-Learning and Knowledge Society, 6(3), $21-30,(2010)$.

3. Taber, K. S., \& Coll, R. K. Chemical bonding. In J. K. Gilbert, O. de Jong, R. Justi, D. F. Treagust \& J. H. Van Driel (Eds.), Chemical Education: Research-based Practice (pp. 213-234). Dordrecht: Kluwer Academic Publishers BV., (2002).

4. Jonassen, D. H. Assessing cognitive structure: Verifying a method using pattern notes. Journal of Research and Development in Education, 20(3), 1-14, (1987).

5. Ifenthaler D., Masduki I. \& Seel N. M., The mystery of cognitive structure and how we can detect it: tracking the development of cognitive structures over time. Instructional Science, 39(1), 41-61, (2009).

6. Özdemir, B. Küresel kirlenme, sürdürülebilir ekonomik büyüme ve çevre vergileri. Maliye Dergisi, 156, (2009). 
7. Chang, C-Y., Yeh, T-K., \& Barufaldi, J. P. The positive and negative effects of science concept tests on student conceptual understanding. International Journal of Science Education, 32(2), 265-282, (2010).

8. Oskay, Ö. Ö., Temel, S., Özgür, S. D., \& Erdem, E. Determination of preservice chemistry teachers' cognitive structures via flow map method and their knowledge level on "greenhouse gases and their effects" topic. Eurasian Journal of Physics \& Chemistry Education, 4(1), 30-45, (2012).

9. Selvi, M., \& Yakışan, M. Akış haritaları yoluyla öğrencilerin bilişsel yapılarının belirlenmesi: Ekolojik döngüler. Türk Fen Ĕ̆itimi Dergisi, 2(1), 46-55, (2005).

10. Akkutay, E. A. Yükseköğrenimde küreselleşme ve yansımaları. Eğitim ve Toplum Araştırmaları Dergisi/JRES, 4(1), 1-16, (2017).

11. Dağlı, A. Küreselleşme karşısında Türk eğitim sistemi. D. Ü. Ziya Gökalp Eğitim Fakültesi Dergisi, 9, 1-13, (2007).

12. Eser, E. Küreselleşme süreci ve eğitime etkisi. Muş, Alparslan Üniversitesi Sosyal Bilimler Dergisi, 2(2), (2014).

13. Korkmaz, M. Küreselleşen dünyada eğitimin küreselleşmesi. Ar\&Ge Bülten, Temmuz-Ağustos, (2015).

14. Gürbüz, Z. Sosyal bilgiler öğretmen adaylarının küreselleşmeye yönelik görüşleri. Yüksel lisans tezi. Marmara Üniversitesi, Eğitim Bilimleri Enstitüsü, İstanbul, (2015).

15. Fidan, S. (2011). Küreselleşme Surecinde Türkiye'de Gençliğin Kimlik Algisı (Üniversite Gençliği Üzerine Bir Araştırma). Doktora Tezi. Sakarya Üniversitesi. Sosyal Bilimler Enstitüsü.

16. Kaya, P. Türkiye'de Küreselleşme Tartışmaları. Ankara Üniversitesi. Sosyal Bilimler Enstitüsü. Yüksek Lisans Tezi, (2002).

17. Vulliamy, G. Educational Reform in a Globalised Age: What is globalisation and how is it affecting Education world-wide? 幼兒教保研究期刊, 第 5 期. (2010).

18. Burbules, N., \& Torres, C. (Eds.). Globalization and education: Critical perspectives. New York: Routledge, (2000).

19. Carnoy, M. \& Rhoten, D. What does globalization mean for educational change? A comparative approach. Comparative Education Review, 46(1), 1-9, (2002).

20. Yıldırım, A. \& Şimşek, H. Sosyal Bilimlerde Nitel Araştırma Yöntemleri (8. Baskı). Ankara: Seçkin Yayıncılık, (2011).

21. Patton, M. Q. Qualitative Research \& Evaluation Methods (3rd ed.). Thousand Oaks, CA: Sage, (2002).

22. Miles, B. M., \& Huberman, A. M. Qualitative data analysis: An extended sourcebook. (2nd edition). Thousand Oaks, CA: Sage, England, (1994). 